\title{
Government Debt Denomination Policies before and after the EMU Advent
}

\author{
November 3, 2011
}

\begin{abstract}
Through a cost-minimizing approach, this paper derives four joint indicators to assess the efficiency of the mix of sovereign debt currencies between the countries belonging to the European Monetary Union (EMU). This theoretical insight enables us to explain why and how the introduction of the euro and the adoption of a common monetary policy may have led to significant changes in debt structure among EMU members, notably in favor of further euro-denominated debt. The interplay of intrinsic and strategic variables yields stylized facts that are consistent with country-specific empirical evidence. Following the sovereign debt crisis, we further emphasize the value-added of a coordinated debt issuance policy among EMU countries.
\end{abstract}




\section{Introduction}

The 2010-11 European sovereign debt crisis, triggered by concerns over the credit risk of the Greek government debt, has shown that euro-denominated bond spreads are largely driven by direct default risk. The common currency acts as a cushion against the temptation to perform competitive devaluations to avoid mere default by distressed governments. This case emphasizes that the adoption of a common monetary policy has substantially altered the market perception of the key drivers of sovereign debt value. This major breakthrough nevertheless has raised many questions about the evolution of yield spreads for fixed income securities issued by the Eurosystem member countries. Investors and other market participants scrutinize for (un)sustainable debt levels and country's debt vulnerability in valuing sovereign debt. Fiscal deficits and projections for the debt-to-GDP ratio are standard indicators for investors to assess the riskiness of a country's sovereign debt. However, these indicators alone do not reflect the whole situation of a country's debt. It is also relevant for investors to review the (in)appropriateness of the country's currency debt structure (proportion of domestic currency denominated debt vs. foreign currency denominated debt) and its maturity profile. From that perspective, no indicator can be looked at in isolation. Moreover, if the euro triggered a noticeable change in the relative cost of domestic and foreign debt of European Monetary Union (EMU) member states, one should also observe a corresponding shift in the debt management indicators. These questions are addressed in this paper.

We adopt a cost-minimizing approach to the problem of defining the appropriate mix of debt currencies with their associated maturities by sovereign governments, which should be their formal goal to reassure investors about their debt management process. Our approach entails the existence of a complete market, which implies that the government's political commitment is firmly set and known by market participants at the very moment of the review of debt composition. Consequently, we take as given the level and expected evolution of taxes and government expenditures, which have been firmly set and communicated to the market. Nevertheless, the impact of these sovereign decisions on the current and future costs of debt is accounted for.

Under the framework developed by Duffie and Singleton (1999), the yearly cost of sovereign debt is represented by its continuous yield spread. The objective function to minimize should thus be the sum of the total cost incurred over the lifetime of debt denominated in domestic and in foreign currency. Such an approach allows us to stick to the financial modeling of yield spreads and to focus on the identification of their determinants. To be convincing, the decision of issuing domestic or foreign debt with their respective 
maturities by a government obviously implies a trade-off between the costs associated with each type of issue. Such costs are likely to be different for countries from outside or inside the EMU, but also among members, depending on whether debt policies are coordinated or not. To assess the appropriateness of both debt structure and maturity profile, we derive four composite indicators throughout our theoretical framework: the intrinsic and strategic default, devaluation (including inflation), liquidity, and the exchange rate risk. These four debt efficiency indicators must be taken into account altogether since the outcome will be the result of an interplay between them. The optimal solution that we obtain is an explicit function of these four sources of risk. It enables us to consider the sources and direction of changes in yield spreads consecutive to the EMU advent, and to deliver theoretical results regarding the predicted change in debt currency composition after the adoption of the euro.

Our modeling approach also allows us to identify a potential improvement in the way governments could finance at the lowest possible cost. A central, coordinated approach to determine debt levels and maturities would result in a Pareto efficient equilibrium. The idea of Euro bonds raised in September 2011 was a step in that direction, but it was motivated by urgency. Long-term economic gains shared across the EMU countries could be achieved by designing a more structural mechanism. The theoretical directions of our framework are matched with data collected on ten EMU member countries during the immediate pre- and post-EMU period. Through evidence gathered from the evolution of debt-related variables, our empirical results indicate that the predicted directions of policy changes are overall consistent with the observed evolution in sovereign debt data.

The next section reviews the evolution of the sovereign debt structure issued by EMU members before and after the advent of the euro in 1999. Section III proposes a theoretical model deriving the optimal currency structure for countries that do not belong to a monetary union. Section IV analyses the impact of the EMU on the model. Section V matches the theoretical predictions with stylized facts. Section VI concludes.

\section{Evolution of the debt characteristics of EMU members}

Overall, the literature reaches a broad consensus on the regime switch within the dynamics of sovereign bond spreads triggered by the achievement of the EMU. Following the removal of exchange rate risks, Wolswijk and de Haan (2006) find that the strategies of government debt managers in the EMU countries have evolved towards a convergence of practices since the introduction of the euro. Two key features among these countries 
are the decline in the share of the debt denominated in non-euro currencies and the tendency to issue plain vanilla bonds. In this respect, Gilson and Gérard (2002) state that a decrease in foreign currency denominated debt will be observed when a central bank starts to be perceived as a credible institution able to commit to low inflation.

Yield spread decomposition is essential for deriving policy implications (Manganelli and Wolswijk 2009). Credit risk stands as an important determinant of the spread of government debt denominated in foreign currencies. It is associated with market discipline and the sustainability of public finances. Codogno et al. (2003), Geyer et al. (2004), Jankowitsch et al. (2006), Beber et al. (2009) and Favero et al. (2010) document that the default risk premium is lower for the first years of the EMU. More recently, however, sovereign credit spreads surged following the 2007 financial crisis and a risk transfer from the financial to the public sector (Attinasi et al. 2009, Eijsing and Lemke 2011). However, Governments with relatively favorable fiscal positions may benefit from lower relative borrowing costs in times of crises, while increasing fiscal deficits are likely to increase spreads across all countries (Haugh et al. 2009, Attinasi et al. 2009). Arnold and Lemmen (2001) also argue that the EMU has increased credit risk by denying governments the emergency exit of money creation.

Liquidity risk is another component of yield spreads, translating imperfect bond market integration. Jankowitsch et al. (2006), Gomez-Puig (2006), Beber et al. (2009), Manganelli and Wolswijk (2009), and Favero et al. (2010) generally find that liquidity effects play a non-trivial role but cannot alone explain the size of the cross-EMU government bond yield spreads. Such a point of view is consistent with Bernoth et al. (2004), who find that the liquidity premium is reduced with EMU membership.

Tables 1 reports key average rates and debt data for 10 EMU countries ${ }^{1}$ during the time window surrounding the freezing date of parities of local currencies against the euro (January 1, 1999). The window is split between the pre-EMU (1994-1998) and the post-EMU (1999-2010) periods. The country of reference for the spread computations is Germany, which has the strongest currency and the lowest inflation among the EMU members. (Daily) swap rate and 10-year benchmark government bond yield data come from Thomson Financial Datastream. Public debt data come from the Central Government Debt statistical yearbook, published annually by the Organization for Economic Cooperation and Development (OECD). Data reported in this publication usually originate from central banks and public debt agencies.

\footnotetext{
${ }^{1}$ Luxembourg and Greece do not report sufficient data and are therefore omitted.
} 
Insert Table 1 approximately here

In Table 1, as in Favero et al. (1997), Blanco (2001), Codogno et al. (2003), and Gomez-Puig (2006, 2008, 2009), we correct the pre-EMU yield spreads for the foreign exchange and inflation component, approximated by the swap differential. The adjusted spread is therefore equal to the difference between the yield spread and the swap spread. Liquidity spreads are computed as the difference in spreads between the yields of the on-the-run and off-the-run 10-year benchmark bonds, which are generally the two most recent issues for this maturity (Warga 1992, Strebulaev 2002, Fleming 2002, Babbel et al. 2004, Jankowitsch et al. 2006). On-therun benchmark bonds are more actively traded and intensively monitored than the off-the-run benchmark. They are therefore very liquid (Fleming 2002, Jankowitsch et al. 2006) and we consider their liquidity premium as negligible, considering the adjusted spread as being essentially associated with default risk.

Swap rates already experienced a strong convergence the year before the introduction of the euro (1998), compared to the preceding years. The swap spread was already relatively smaller for Austria, Belgium, and the Netherlands. They had constituted a core of currencies that were strongly and effectively pegged to the Deutsche Mark inside the European Monetary System (EMS). The largest spreads are found for the higherinflation volatile currencies of the Southern states (Italy, Portugal, Spain). But even for those countries, a sharp reduction of the spread is observed, as the introduction of the euro approaches. As for the adjusted spread, we observe that the exchange rate/inflation factor proxied by the swap spread heavily affected the yield spread for many countries, especially for Southern countries, which is consistent with Blanco (2001) and Favero et al. (2010).

Post-EMU liquidity spreads are lower than default spreads, as already evidenced by many authors (Codogno et al. 2003, Geyer et al. 2004, and Jankowitsch et al. 2006), except in Ireland. The largest countries appear to be the most liquid markets (Germany, France and Italy), as expected according to the traditional positive link between size and liquidity (Warga 1992, Crabbe and Turner 1995). By contrast, Finland and Ireland exhibit larger liquidity spreads before the EMU, which can justify higher shares of foreign currency debt. Liquidity has particularly improved for Finnish bonds since the launch of the EMU. Slight increases in liquidity spreads can be observed for Germany, Austria, France, the Netherlands and Spain after 1999. Limited bond supply due to improving public finances could explain this pattern. These results are consistent with the evidence shown by Manganelli and Wolswijk (2009) and Beber et al. (2009) who support 
the existence of a positive liquidity risk premium after the EMU.

According to the Maastricht Treaty criteria, countries that were more heavily indebted before the EMU, such as Belgium and Italy, have continuously decreased the total debt-to-GDP ratio in order to approach the target of $60 \%$. Regarding the currency composition of national debt, a clear decline in the proportion of the debt denominated in foreign (non-euro) currencies can be observed, with the exception of Spain. Prior to adopting the euro, most of the members' foreign debt is denominated in currencies of other (future) EMU members. It not therefore surprising to observe a specific decline in foreign debt in 1999, but the decline continues during the subsequent years thereafter in any case. Unquestionably, the euro has also allowed the EMU members to increase the proportion of government securities held by non-residents, which indicates that the markets for debt issued by the EMU member countries have reinforced their integration. This phenomenon is in line with a phenomenon of reinforcing the role of default risk and reducing the impact of inflation and devaluation risk in the spread processes, with a limited role of liquidity risk.

In the next sections, we develop a framework that aims at capturing the shift in sovereign debt currency, while controlling for debt maturity, consecutive to the adoption of euro as a common currency in EMU.

\section{Indicators without the EMU}

We first derive the efficiency indicators before the advent of the EMU. When market participants scrutinize sovereign debt in the absence of the EMU, they must take into account the possibility afforded to the government to levy on inflation or on devaluation. These actions serve as tools to decrease the real value of domestic debt and thus to capture an indirect tax (see Bohn, 1988; Bohn, 1990; Miller, 1997). Investors monitor these risks and demand a compensation for bearing them. For the government, the existence of the Eurozone yields effects similar to the interdiction of issuing money, which applies to any province, state or other public issuer. The main difference with the countries adhering to the EMU is that, in their case, they transit from the absence to the presence of EMU, and so we can observe and dissect the impact for investors of their loss of sovereignty.

\section{A. Model setup}

Two economies, the domestic and the foreign one, use a different currency, $u_{D}$ and $u_{F}$ respectively. The domestic government can issue debt in domestic or in foreign currency units on the debt market. This government has a target debt maturity $T$ and wishes to pay back a given amount in real terms, normalized 
to 1 unit of the foreign currency, by issuing zero-coupon bonds. When defining its debt structure, it chooses the face value $D$ of debt issued in the domestic currency, given that the face value of the foreign debt is the residual amount $F=1-D$. The government can also set the debt maturities, $T_{D}$ for domestic debt and $T_{F}$ for foreign debt, provided that the average maturity, weighted by face value, is equal to $T: D T_{D}+F T_{F}=T$. Face value and average debt maturity are exogenously defined by the government. Debt mix should be chosen so as to minimize the aggregate interest cost of debt.

The government is already locked into the current fiscal and monetary policies, as well as the level of government expenditures. The impact of these policies is summarized by the stochastic process of the total debt to the GDP, named $\Gamma(t)$, represented by the following Arithmetic Brownian Motion:

$$
\ln \Gamma(t)=2 \gamma_{0}+\gamma_{1} t+2 \sigma_{\gamma} Z_{\gamma}(t)
$$

where $Z_{\gamma}(t)$ is the time- $t$ value of a one-dimensional Brownian Motion ${ }^{2}$. Standard useful indicators for investors are coefficients $\gamma_{0}$ and $\gamma_{1}$ representing the political commitment to the government's public deficit, and $\sigma_{\gamma}$ standing for the volatility of public deficits due to random shocks to the economic and political conditions. In particular, the linear time trend can be interpreted by market participants as a political commitment to increase or decrease deficits along a given political line. A value of $\gamma_{1}=0$ stands for a commitment to a steady evolution of the debt ratio ${ }^{3}$. As we focus on the differential impact of the proportion of domestic and foreign debt in the spread components, the debt process is further decomposed in a domestic and a foreign part $\ln \Gamma(t)=\ln \Gamma_{F}(t)+\ln \Gamma_{D}(t)$ where:

$$
\ln \Gamma_{j}(t)=\gamma_{0}+\gamma_{j} j . t+\sigma_{\gamma} Z_{\gamma}(t), \quad j=D, F
$$

The definition of the cost of debt should be independent of the country's monetary policy. Thus, it is computed in foreign currency units. Assuming that the existence of a nominal money market account is guaranteed for each economy, the exchange rate process $X(t)$ between $u_{D}$ and $u_{F}$ follows a Geometric Brownian Motion represented by:

$$
X(t)=X(0) \exp \left\{\left(x_{0}+x_{t} D\right) t+\sigma_{x} Z_{x}(t)\right\}
$$

\footnotetext{
${ }^{2}$ All processes are expressed under the risk-adjusted probability measure, which is assumed to exist for each type of risk.

${ }^{3}$ We prefer this specification to a Ornstein-Uhlenbeck process because the evolution of the debt ratio is an essential tool of budgetary policies, and so one should observe a firm drift in this ratio corresponding to a particular political orientation.
} 
where $x_{0}$ represents the structural drift of the exchange rate process, $x_{t}$ reflects the market impact of the government's debt management, and $Z_{x}(t)$ is a SBM and $\operatorname{corr}\left(Z_{x}(t), Z_{\gamma}(t)\right)=\rho_{x \gamma}$. Meese and Rogoff (1983) show that a simple random walk model of the exchange rate performs as well as any other one. The introduction of $D$ in the drift term is the natural consequence of the effect of the proportion of domestic debt on the inflation level and process as well as on the government's incentive to devaluate. A negative value of $x_{0}$ or $x_{t}$ means respectively that $u_{F}$ is weaker than $u_{D}$, or that the management of public deficits is less effective in the foreign country.

A government seldom makes an outright default. Rather, it may repeatedly force debt restructuring or renegotiation (Bulow and Rogoff, 1989). For this reason, government debt can be priced using similar reduced-form models of default credit (and other) events, as suggested by Duffie and Singleton (1999). These authors show that we can allow for default risk (and other possible risks) by replacing the discount rate $r(t)$ with a default-adjusted discount rate $r(t)+s(t)$. When default (or another event) occurs, bondholders recover a fraction proportional to the pre-default market value, which is still subject to default risk. In this study, we are interested in minimizing the spreads $s(t)$ associated with the various risks of the bond. The cost of debt is then defined as the average yield spread to maturity of each type of debt, expressed in foreign currency units, weighted by the corresponding promised amount and maturity. In order to stick to the effect of debt composition on this weighted average cost, we assume an independent interest rate process. The cost function is thus:

$$
C(0)=D T_{D} Y_{D}\left(T_{D}\right)+F T_{F} Y_{F}\left(T_{F}\right)
$$

where $Y_{j}\left(T_{j}\right), j=D, F$ is the annual yield spread to maturity of a zero-coupon bond issued by the domestic government, expressed in currency $u_{F}$, respectively on the domestic and the foreign debt market. This cost function can be rewritten as:

$$
C(0)=-D \ln \left[X(0) \mathrm{E}\left(\frac{1}{X\left(T_{D}\right)} \exp \left\{-\int_{0}^{T_{D}} s_{D}(u) d u\right\}\right)\right]-F \ln \left[\mathrm{E}\left(\exp \left\{-\int_{0}^{T_{F}} s_{F}(u) d u\right\}\right)\right]
$$

where $s_{j}(t), j=D, F$ is the spot spread of a zero-coupon issued by the domestic government respectively on the domestic and the foreign debt market. Through this cost function, the government attempts to minimize the weighted average cost of debt to convince the market of the effectiveness of its debt management.

To derive our indicators, our main challenge is to characterize the term structure of spreads associated with domestic and foreign debt. In addition to default risk, sovereign spreads should capture the risks of 
surprise inflation and currency devaluation as these factors threaten bond value. The existing literature suggests that the main determinant of the spread of foreign debt would be default risk, whereas devaluation and inflation risks would primarily affect domestic debt . Kremer and Mehta (2000) study a model in which governments are more inclined to default if a large proportion of their debt is held by foreigners, because each government cares about the welfare of its citizens. The authors extend their model to include a government that could credibly commit to repaying but that prefers to issue domestic-currency-denominated debt rather than foreign-currency-denominated debt. Claessens et al. (2004) show that higher inflation is associated with a higher share of domestic currency debt.

Devaluation and default are voluntary actions taken by the government. These decisions can be triggered by shocks similar to the ones affecting the ratio of debt over GDP, but they can also be motivated by the government's debt management strategy. Ex ante, on efficient debt markets, this propensity to devaluate or to default on debt would be recognized by the market participants and the government in question would be penalized by the proceeds of debt issues through a higher risk premium.

Default risk, although in principle avoided on the domestic market through the ability to print money, could affect domestic debt because the social benefit of the relief of debt pressure may exceed the additional political cost of defaulting on domestic together with foreign debt (Nielsen, 1999). Similarly, financial markets might fear that a devaluation could lead the country to weaken its potential ability to pay off foreign debt in case of trouble, because of the increase in the political and social costs of a further devaluation.

Finally, a potential explanation for sovereign spreads relates to liquidity issues (Amihud and Mendelson, 1991; Warga, 1992; Kamara, 1994; Krishnamurthy, 2002). Investors may require a liquidity premium for holding "illiquid" assets in order to reward them for bearing higher transaction costs, including taxes. The relative lack of liquidity of debt denominated in the (less liquid) domestic currency unit can lead a government to issue greater debt in foreign currency units. Similarly, the liquidity premium on foreign debt can be conditional on the liquidity level of the domestic debt, given the smaller number of market participants.

We therefore consider that the foreign spread is made up of three components: one related to direct credit risk, and two relating to the indirect effects of devaluation and liquidity risk. Similarly, the domestic spread involves four components: two due to direct devaluation and liquidity risks (the former incorporating inflation risk), and one due to indirect default risk. Since all these risks are manifested through risk premiums, they 
are considered to be additive. They exhibit the following structure:

$$
s_{j}(t)=\Phi_{j}(t)+\Delta_{j}(t)+\Psi_{j}(t)
$$

where $j=D, F$. The first term $\Phi_{j}$ represents the default spread; $\Delta_{j}$ is the devaluation spread, where the domestic spread includes inflation risk; and $\Psi_{j}$ stands for the liquidity spread.

\section{B. Debt valuation}

Parsimony is necessary to derive interpretable optimality results and to analyze the subsequent comparative statics. We assume all spreads in equation (6) to be normally distributed with no mean-reversion. ${ }^{4}$ Consider first default risk. Unlike companies, governments cannot simply go bankrupt, because their country cannot be merely liquidated. Rather, the state of default is likely to be associated to the incapacity of meeting coupon payments, or to the willingness to scale down the face value of outstanding debt. These situations involve both a proportion of debt remaining alive after default and, more importantly, that remaining debt still being submitted to the future default risk of the very same country (Diamond and Dybvig, 1983). The reduced-form model of default proposed by Duffie and Singleton (1999), who represent the spread as the product $s(t)=h(t) l(t)$ where $h(t)$ is the arrival rate of default and $l(t)$ is the loss rate upon default, is particularly suited to this situation. ${ }^{5}$ For the case of foreign debt, intrinsic default risk is the primary component of the cost of debt. It is mostly the outcome of a political decision by the government and the level of risk aversion. In addition, the average remaining maturity of this type of debt, $\left(T_{F}-t\right)$, weighted by the proportion of foreign debt, $F$, influences the decision to default. A high weighted average time to maturity negatively affects the incentive to default on foreign debt (consistent with Missale and Blanchard, 1994), because of the negative relationship between maturity and the present value of a zero-coupon debt. We thus find the product $F\left(T_{F}-t\right)$ in the spread definition. Finally, some decisions to default depend on the total stock of debt to GDP, sensitive to the composition of new debt and to unexpected shocks in economic conditions, which is represented by process $\ln \Gamma_{F}(t)$. This is in line with Faini (2006) who finds that fiscal

\footnotetext{
${ }^{4}$ The choice of an Ornstein-Uhlenbeck or a square-root process, which both feature a mean-reverting behavior, might better reflect policy changes in the long run, but the gain in the spread specification would not be significant while it would add useless complexity in the model. The requirement that spreads are linear is not too stringent, because it is not a strict pricing exercise. We explicitly ruled out the Geometric Brownian Motion specification because it involves a lognormal behavior of the spreads and rules out negative values of the spreads. Such a requirement should not hold at all in the paper.

${ }^{5}$ The case of the Greek sovereign debt, whose rescue plan design by the EU involved a write-off of part of the debt but no outright default, illustrates the relevance of this assumption.
} 
policy and debt levels significantly affect both sovereign bond spreads and the overall level of interest rates in the EMU. Thus, we characterize the foreign default spread as:

$$
\Phi_{F}(t)=\phi_{0}+\phi_{t} F\left(T_{F}-t\right)+\phi_{\gamma} \ln \Gamma_{F}(t)
$$

To get the indirect effect of default risk on the domestic spread, the arrival risk of default is lowered by a fraction corresponding to the additional social cost of defaulting on domestic debt. The trade-off between $D$ and $T_{D}$ is essentially similar as for foreign debt. This yields the following:

$$
\Phi_{D}(t)=\alpha\left[\phi_{0}+\phi_{t} D\left(T_{D}-t\right)+\phi_{\gamma} \ln \Gamma_{D}(t)\right]
$$

where $\alpha$ represents the propensity to default on domestic debt conditional on defaulting on foreign debt. It is negatively related to the social and political costs of domestic default (see Alesina et al., 1992).

The analysis of devaluation spreads is very similar. Devaluation involves a sudden drop in the market value of debt, with its associated arrival and magnitude risks. The domestic spread is directly affected by this risk, while the foreign spread only bears this risk indirectly. The reasons for devaluing are essentially of the same kind as for defaulting: political, strategic (and therefore related to the level of domestic debt and to its maturity) and stochastic. In addition, the domestic devaluation spread integrates the government's incentive to control inflation, since it benefits from an "inflation tax" on its outstanding domestic debt (Giavazzi and Pagano, 1990, Claessens et al. 2004). The spreads exhibit a structure similar to the default risk ones:

$$
\begin{aligned}
& \Delta_{D}(t)=\delta_{0}+\delta_{t} D\left(T_{D}-t\right)+\delta_{\gamma} \ln \Gamma_{D}(t) \\
& \Delta_{F}(t)=\beta\left[\delta_{0}+\delta_{t} F\left(T_{F}-t\right)+\delta_{\gamma} \ln \Gamma_{F}(t)\right]
\end{aligned}
$$

where $\beta$ is the indirect market impact of a devaluation of the domestic currency on the foreign debt; it is an indicator of market confidence. Note that if the Fisher effect holds perfectly, we have that $\delta_{0}+\delta_{\gamma} \gamma_{0}=x_{0}$ and $\delta_{t}-\delta_{\gamma} \gamma_{D}=x_{t}$, as the impact of devaluation risk offsets the expected currency depreciation: only unexpected currency and devaluation risks remain. We do not net devaluation with currency risks however, because these two processes do not necessarily offset each other in the post-EMU situation.

As for liquidity spreads, we can use a similar approach, with the direct impact set on the domestic spread:

$$
\begin{aligned}
& \Psi_{D}(t)=\psi_{0}+\psi_{t} D\left(T_{D}-t\right)+\psi_{\gamma} \ln \Gamma_{D}(t) \\
& \Psi_{F}(t)=\mu\left[\psi_{0}+\psi_{t} F\left(T_{F}-t\right)+\psi_{\gamma} \ln \Gamma_{F}(t)\right]
\end{aligned}
$$


where $\mu$ is the indirect market impact of the (il)liquidity on the foreign debt.

This complete characterization of the spread processes enables us to assess the cost of financing through the following Proposition (all proofs are available upon request):

Proposition 1 The cost of financing one face value unit of government debt through a proportion $D$ of domestic debt with maturity $T_{D}$ and the rest of foreign debt, with an average maturity of $T$, is given by:

$$
\begin{gathered}
C(0)=K_{00}+K_{11} D T_{D}+K_{21} D^{2} T_{D}+K_{22} D^{2} T_{D}^{2} \\
K_{00}=\quad T\left[\phi_{0}+\beta \delta_{0}+\mu \psi_{0}+\gamma_{0}\left(\phi_{\gamma}+\beta \delta_{\gamma}+\mu \psi_{\gamma}\right)+\frac{1}{2}\left[\phi_{t}+\beta \delta_{t}+\mu \psi_{t}+\gamma_{F}\left(\phi_{\gamma}+\beta \delta_{\gamma}+\mu \psi_{\gamma}\right)\right] T\right. \\
\\
\left.\quad-\frac{1}{2}\left(\phi_{\gamma}^{2}+\beta^{2} \delta_{\gamma}^{2}+\mu^{2} \psi_{\gamma}^{2}\right) \sigma_{\gamma}^{2}\right] \\
K_{11}=x_{0}+\left[-\phi_{\gamma}(1-\alpha)+\delta_{\gamma}(1-\beta)+\psi_{\gamma}(1-\mu)\right] \gamma_{0}+(1-\beta) \delta_{0}-(1-\alpha) \phi_{0}+(1-\mu) \psi_{0} \\
\quad+T\left(\phi_{t}+\beta \delta_{t}+\mu \psi_{t}\right)-\frac{V}{2} \\
K_{21}=x_{t} \\
K_{22}=\frac{1}{2}\left[-(1-\alpha) \phi_{t}+(1-\beta) \delta_{t}+(1-\mu) \psi_{t}+\left(\alpha \phi_{\gamma}+\delta_{\gamma}+\psi_{\gamma}\right) \gamma_{D}-\left(\phi_{\gamma}+\beta \delta_{\gamma}+\mu \psi_{\gamma}\right) \gamma_{F}\right] \\
V=\sigma_{\gamma}^{2}\left[\left(1-\beta^{2}\right) \delta_{\gamma}^{2}-\left(1-\alpha^{2}\right) \phi_{\gamma}^{2}+\left(1-\mu^{2}\right) \psi_{\gamma}^{2}\right]+\sigma_{x}^{2}+2\left[\left(\rho_{\gamma x} \sigma_{x} \sigma_{\gamma}\right)\left(\delta_{\gamma}+\psi_{\gamma}+\alpha \phi_{\gamma}\right)\right]
\end{gathered}
$$

Proposition 1 represents the basis for the analysis of sovereign debt management by market participants. The cost function appears to be quadratic in the strategic arguments. The subsequent analysis is developed for a government whose only strategic variable is the proportion of domestic debt, leaving maturity constant. ${ }^{6}$

\section{Optimal debt mix}

If the government sets identical maturities for domestic and foreign debt, the optimization problem has one strategic variable $D$. Denoting $T$ single maturity of all debt, the solution to this problem has the form:

Proposition 2 If the maturities of foreign and domestic debt are equal to a constant $T$, the optimal proportion of domestic debt, denoted $D^{\text {opt }}$, is given by:

$$
D^{o p t}= \begin{cases}0 & \text { iff } Y \geq 0 \text { and } X+Y \geq 0 \\ D^{*}=\frac{-K_{11}}{2\left(K_{21}+K_{22} T\right)} & \text { iff } 2 X+Y>0 \text { and } Y<0 \\ 1 & \text { iff } 2 X+Y \leq 0 \text { and } X+Y<0\end{cases}
$$

\footnotetext{
${ }^{6}$ The joint determination of optimal debt mix and maturities produces similar results. To save space, it is left out of the paper. Detailed results are available upon request.
} 
where $Y=K_{11}$ and $X=K_{21}+K_{22} T$.

The first case, leading to an optimal decision to borrow entirely on the foreign market, involves the fact that $Y \geq 0$ and that $X$ is positive or negative provided $|X| \leq Y$. The qualitative analysis depends on the maturity: if $T$ is high, $K_{22}$ will be dominant in $X$, whereas $K_{21}$ is the driver for low values of $T$. The decisions to borrow fully on the domestic or on the foreign market must be scrutinized with different elements depending on whether short term or long term debt is issued.

Consider first short term debt. A government should choose to borrow the entire amount on the foreign market when the default, liquidity and devaluation risks indicator, $K_{11}$, is positive. In particular, this is favored by the following circumstances: the domestic currency is intrinsically weaker than the foreign currency $\left[x_{0}\right]$, the net intrinsic devaluation $\left[(1-\beta) \delta_{0}\right.$ and $\left.(1-\beta) \delta_{\gamma} \gamma_{0}\right]$ and liquidity risks $\left[(1-\mu) \psi_{0}\right.$ and $\left.(1-\mu) \psi_{\gamma} \gamma_{0}\right]$ are high, while the net intrinsic default risk $\left[-(1-\alpha) \phi_{0}\right.$ and $\left.-(1-\alpha) \phi_{\gamma} \gamma_{0}\right]$ is low and the total variance of all sources of risks $[V]$ is low. None of these factors encompasses parameters whose choice can be strategically set by the government to minimize the cost of debt; rather, they are the ones on which the government has the lowest impact. The likelihood of not borrowing short term on the domestic market increases for a high enough value of the strategic exchange rate risk indicator, $K_{21}$, i.e. a positive or not too negative level of the impact of debt management on the exchange rate in the foreign economy $\left[x_{D}\right]$, which has a one-shot effect on the total cost function through the expected exchange rate at maturity. This variable is more under the government's control than the components of $K_{11}$, but its influence on the cost of debt is lower than variables impacting directly on spreads. It plays the role of an adjustment instrument.

For long term debt, all these factors have a lesser impact. The elements favoring foreign debt are now a low level of strategic devaluation, default and liquidity risk on foreign debt $\left[\phi_{t}+\beta \delta_{t}+\mu \psi_{t}\right]$ (appearing in $K_{11}$ ). For long maturities, these effects would not be totally dashed by the effect of our fourth indicator, $K_{22}$. The expression appearing in this term deserves discussion. One can grasp the intuition underlying this expression by writing $\left[\left(\alpha \phi_{t}+\delta_{t}+\psi_{\gamma}+\pi_{t}\right)+\left(\alpha \phi_{\gamma}+\delta_{\gamma}+\psi_{\gamma}+\pi_{\gamma}\right) \gamma_{D}\right]-\left[\left(\phi_{t}+\beta \delta_{t}+\mu \psi_{t}\right)+\left(\phi_{\gamma}+\beta \delta_{\gamma}+\mu \psi_{\gamma}\right) \gamma_{F}\right]$ : the first bracket represents the cost obtained by taking on domestic debt, and the second one represents the cost if foreign debt is adopted instead of domestic debt. As a whole, this expression thus represents the total strategic liquidity, devaluation and default effects of domestic borrowing, including its indirect impact on foreign debt. The analysis is very similar for the other corner solution involving $D=1$. 
A government should mix domestic and foreign borrowing when $Y<0$ and $2 X+Y>0$, implying $X>0$. Under the same analysis as before, these conditions mean that intrinsic elements would be favorable to domestic borrowing, but strategic effects suggest the adoption of foreign debt, both for short term and long term debt. Comparative statics for $D^{*}$ in (19) yield Corollary 3, while fixing the debt mix and letting the maturity of domestic and foreign debt vary produces Corollary 4 :

Corollary 3 If the maturities of foreign and domestic debt are equal, the following inequalities obtain:

$$
\begin{cases}D^{*} \leq \frac{1}{2} ; D_{21} \leq-D_{11} ; D_{22} \leq D_{12} & \text { iff } 0<-Y \leq X \\ D^{*}>\frac{1}{2} ; D_{21}>-D_{11} ; D_{22}>D_{12} & \text { iff } 0<X<-Y<2 X\end{cases}
$$

where $D_{i j}=\frac{\partial D^{*}}{\partial K_{i j}} ; i, j=1,2 ; Y=K_{11}$ and $X=K_{21}+K_{22} T$.

Corollary 4 If the optimal proportion of domestic debt, denoted $D^{\text {opt }}$ is fixed, the optimal maturity of domestic debt is equal to $T_{D}^{*}=\frac{-\left(K_{11}+K_{21} D\right)}{2 K_{22} D}$

The pivot value of $D^{*}$, i.e. the one for which the impact of $X$ and of $Y$ is balanced, is found to be $\frac{1}{2}$. Again, there is not much difference in the treatment of long term or short term debt, since the same kinds of tendency are to be observed. The sensitivity of the optimal proportion of domestic debt is indeed related to the ratio $\frac{-Y}{X}$. When $D^{*}$ is in the neighborhood of 0 , this ratio is very low, indicating that the optimal debt ratio is much more sensitive to $D_{11}$ (resp. $D_{12}$ ) than $D_{21}$ (resp. $D_{22}$ ) for short term (resp. long term) debt. Intrinsic characteristics also dominate for low levels of domestic debt.

\section{Indicators in the Presence of the EMU}

Countries adhering to the EMU do not resign their sovereignty over the choice of the optimal debt mix. Rather, their decisions must reflect the changes in devaluation, inflation and default risks. Debt management indicators should be adjusted.

\section{A. Modified model}

The advent of EMU implies that all countries share an identical monetary policy, decided by the European Central Bank (ECB). A single exchange rate, which is influenced by the aggregate inflation process within the EMU, prevails for every country. It is assumed that the ECB would never decide to devalue the euro, as this kind of decision implies a political consensus of all member countries, who can in principle not put any 
pressure on the central bank. Yet, individual countries can indirectly impact on inflation and exchange rates by setting debt levels and maturities, and by defaulting. The primary task of the ECB is to maintain price stability. What are concretely the changes involved for investors?

First, the sovereign debt level process has to be reconsidered. Because of the convergence criteria, countries have to ensure a tighter control of their budget deficit. However, although the necessary debt level relative to GDP and yearly budget deficit were initially set as conditions for entering the EMU, experience shows that this was mainly meant to force a political commitment for "problem" countries like Belgium or Greece. The debt ratio process for any member country $i$ takes this into account, and is split according to each country's domestic and foreign debt components as in equation (2):

$$
\ln \Gamma_{i j}(t)=\gamma_{i 0}+\theta_{i}\left[\gamma_{i j} j_{i} t+\sigma_{i \gamma} Z_{\gamma}(t)\right], \quad j=D, F
$$

where the main change is the intervention of a factor $\theta_{i}$ impacting on the drift and diffusion terms, representing the government's political commitment to control the evolution of debt: if $\gamma_{i 0}>\bar{\gamma}_{0}$ (too high debt level) or if $\gamma_{i t}>\bar{\gamma}_{1}$ (budget deficit out of control), $\theta_{i}<1$ and the country is forced to put all its efforts towards the limitation of deficits, including the ones resulting from unanticipated shocks.

Second, the exchange rate process of the euro with respect to the reference currency applies to all member countries. It has the form:

$$
X^{\prime}(t)=X^{\prime}(0) \exp \left\{\left(\lambda_{x}^{-}+x_{0}^{\prime}+x_{t}^{\prime} \sum_{i} w_{i} D_{i}\right) t+\sigma_{x}^{\prime} Z_{x}^{\prime}(t)\right\}
$$

where $w_{i}$ is the weight of each country's total debt in the total debt issue, and $D_{i}$ is the proportion of this debt denominated in euros. The introduction of this weighted sum makes the exchange rate differ essentially from (3), because each country has an indirect impact through the proportion chosen, although the total debt effect is mainly out of control. For formerly strong currencies like the German mark, $x_{0}^{\prime}>x_{i 0}$ and/or $x_{t}^{\prime}>x_{i t}$, while the reverse holds for weaker currencies. Parameter $\lambda_{x}^{-}$stands for the adverse effects of the lack of credibility of the "no bail out" clause: if market participants believe that the member countries could bail out one of them in case of difficulty, this weakens the euro.

Devaluation risk collapses to inflation risk in the EMU setup, and this risk is common to all countries. Even though each country still experiences its own inflation risk spread, inflation surprise and differentials across countries narrow to persistently low levels. Since the ECB strongly commits to deliver an annual 
inflation rate close to $2 \%$ at the EMU level, there is a sharp convergence in the medium-term inflation rates. The impact of each individual issue is reduced to the weight of each country in the total debt issue in the EMU. The contribution of each country to the aggregate inflation process is accordingly reduced and so the inflation spread. This follows a new spread process:

$$
\Delta^{\prime}(t)=\lambda_{i 0}^{-}+\delta_{i 0}^{\prime}+\left[\delta_{i t}^{\prime} w_{i} D_{i}\left(T_{i D}-t\right)\right]+z_{i} \delta_{i \gamma} \ln \Gamma_{i D}(t)
$$

where $z_{i}$ is another weighting factor, applied to the contribution of each country's inflation process to the overall inflation in EMU. The structural inflation $\left(\delta_{i 0}^{\prime}\right)$, as well as inflation drift $\delta_{i t}^{\prime}$ are expected to translate the ECB's main objective of price stability in the euro-zone. $\lambda_{0}^{-}$represents undesirable effects of bailing out countries in case of virtual default, violating the no bail out clause.

As before, foreign as well as domestic debt are subject to recurrent default risk. The foreign debt spread is represented by a process very similar to equation (7):

$$
\Phi_{F}^{\prime}(t)=\phi_{i 0}^{\prime}+\lambda_{i 0}^{+}+\phi_{i t}^{\prime} F_{i}\left(T_{i F}-t\right)+\phi_{i \gamma}^{\prime} \ln \Gamma_{i F}(t)
$$

and here, $\lambda_{i 0}^{+}$is a cost-reducing term arising from the government's ability to call upon the solidarity of other EMU members in case of virtual default. The other parameters are also likely to be higher than in (7), as there are fewer instruments available for a government to provide a substitute to default through inflation or devaluation. Under the same approach as in the previous section, the domestic default spread writes:

$$
\Phi_{D}^{\prime}(t)=\alpha_{i}^{\prime}\left[\phi_{i 0}^{\prime}+\lambda_{i 0}^{+}+\phi_{i t}^{\prime} D_{i}\left(T_{i D}-t\right)+\phi_{i \gamma}^{\prime} \ln \Gamma_{i D}(t)\right]
$$

Finally, both domestic and foreign debt spreads would still reflect compensation for liquidity risk. The emergence of a larger market size and a broader range of market participants can surely have a beneficial effect on debt liquidity, notably through increasing cross-ownership. However, the fact that government bonds are still issued by separate government debt agencies with different needs, strategies, procedures and instruments may reflect a significant residual fragmentation. Gomez-Puig (2006) highlights the fact that the benefits of the EMU can be partly mitigated by the possible increased competition between euro-area government securities markets. Manganelli and Wolswijk (2009) support the existence of a positive liquidity risk premium after the EMU. In addition, the focus on the 10-year bond segment in combination with a limited bond supply, as a result of improving public finances, can partially explain the presence of a liquidity 
premium. The liquidity spread process presents the following familiar form:

$$
\begin{aligned}
& \Psi_{D}(t)=\psi_{i 0}^{\prime}+\psi_{i t}^{\prime} D_{i}\left(T_{i D}-t\right)+\psi_{i \gamma}^{\prime} \Gamma_{i D}(t) \\
& \Psi_{F}(t)=\mu_{i}^{\prime}\left[\psi_{i 0}^{\prime}+\psi_{i t}^{\prime} F_{i}\left(T_{F}-t\right)+\psi_{i \gamma}^{\prime} \ln \Gamma_{i F}(t)\right]
\end{aligned}
$$

B. Optimal mix for a member country with no coordination of debt policies

Consider first that each government takes as given the level of domestic and foreign debt of all other member countries. It is easy to solve the optimization problem every country should face:

Proposition 5 The cost of financing one face value unit of government debt of member country $i$ through a proportion $D_{i}$ of domestic debt with maturity $T_{i D}$ and the rest of foreign debt, with an average maturity of $T_{i}$, is given by:

$$
\begin{gathered}
C_{i}(0)=K_{i 00}+K_{i 11} D_{i} T_{i D}+K_{i 21} D_{i}^{2} T_{i D}+K_{i 12} D_{i} T_{i D}^{2}+K_{i 22} D_{i}^{2} T_{i D}^{2} \\
K_{i 00}=T_{i}\left[\phi_{i 0}^{\prime}-\lambda_{i 0}^{+}+\mu_{i}^{\prime} \psi_{i 0}^{\prime}+\gamma_{i 0}\left(\phi_{i \gamma}^{\prime}+\mu_{i}^{\prime} \psi_{i \gamma}^{\prime}\right)+\frac{1}{2}\left[\phi_{i t}^{\prime}+\mu_{i}^{\prime} \psi_{i t}^{\prime}+\theta_{i} \gamma_{i F}\left(\phi_{i \gamma}^{\prime}+\mu_{i}^{\prime} \psi_{i \gamma}^{\prime}\right)\right] T_{i}\right. \\
\left.-\frac{1}{2}\left(\phi_{i \gamma}^{\prime 2}+\mu_{i}^{\prime 2} \psi_{i \gamma}^{\prime 2}\right) \theta_{i}^{2} \sigma_{i \gamma}^{2}\right] \\
K_{i 11}=\lambda_{i 0}^{-}+\delta_{i 0}^{\prime}+\theta_{i} \gamma_{i 0}\left[-\phi_{i \gamma}^{\prime}\left(1-\alpha_{i}^{\prime}\right)+\psi_{i \gamma}^{\prime}\left(1-\mu_{i}^{\prime}\right)+z_{i} \delta_{i \gamma}\right]+\lambda_{x}^{-}+x_{0}^{\prime}+x_{t}^{\prime} \sum_{j \neq i} w_{j} D_{j} \\
K_{i 21}=w_{i} x_{t}^{\prime} \\
K_{i 22}=\frac{1}{2}\left[-\left(1-\alpha_{i}^{\prime}\right)\left(\phi_{i 0}^{\prime}-\lambda_{i 0}^{+}\right)+\left(1-\mu_{i}^{\prime}\right) \psi_{i 0}^{\prime}+T_{i}\left(\phi_{i t}^{\prime}+\mu_{i}^{\prime} \psi_{i t}^{\prime}\right)-\frac{1}{2} V_{i}^{\prime}\right. \\
V_{i}^{\prime}=\theta_{i}^{2} \sigma_{i \gamma}^{2}\left[-\left(1-\alpha_{i}^{\prime 2}\right) \phi_{i \gamma}^{\prime 2}+\left(1-\mu_{i}^{\prime 2}\right) \psi_{i \gamma}^{\prime 2}+z_{i}^{2} \delta_{i \gamma}^{2}\right]+\sigma_{x}^{\prime 2} \\
+2 \theta_{i}\left[\rho_{\gamma x}^{\prime} \sigma_{x}^{\prime} \sigma_{\gamma}^{\prime}\left(\alpha_{i}^{\prime} \phi_{i \gamma}^{\prime}+\psi_{i \gamma}^{\prime}+z_{i} \delta_{i \gamma}\right)\right]
\end{gathered}
$$

Corollary 6 If the maturities of foreign and domestic debt are equal to a constant $T_{i}$, the optimal proportion of domestic debt for country $i$, denoted $D_{i}^{o p t}$, is given by:

$$
D_{i}^{o p t}= \begin{cases}0 & \text { iff } Y_{i} \geq 0 \text { and } X_{i}+Y_{i} \geq 0 \\ D_{i}^{*}=\frac{-K_{i 11}}{2\left(K_{i 21}+K_{i 22} T_{i}\right)} & \text { iff } 2 X_{i}+Y_{i}>0 \text { and } Y_{i}<0 \\ 1 & \text { iff } 2 X_{i}+Y_{i} \leq 0 \text { and } X_{i}+Y_{i}<0\end{cases}
$$

where $Y_{i}=K_{i 11}$ and $X_{i}=K_{i 21}+K_{i 22} T_{i}$. The cases mentioned encompass all possible parameter values. 
Compared with the preceding section, there are some differences to be discussed in the composition of the constants. First, investors should notice that the influence of each country's strategic management factors on the exchange rate and inflation is much lower in the EMU. They impact $K_{i 21}$, through $w_{i} x_{D}^{\prime}$, and $K_{i 22}$ through $w_{i} \delta_{i t}^{\prime}$. No government controls $x_{D}^{\prime}$,or $\delta_{i t}^{\prime}$ which is set at the pan-European level. Their signs depend on the strength of the global monetary policy, but they drive the national borrowing choices. If they are negative, corresponding to a tight policy compared to the reference economy, $K_{i 21}<0$ and $K_{i 22}<0$. This case corresponds to full domestic borrowing for all countries. If the debt policy is perceived as permissive, which is the case if $x_{t}^{\prime}>0$ and $\delta_{i t}^{\prime}>0$, then $K_{i 21}>0$ and $K_{i 22}$ decreases. Furthermore, the weight of the country in total debt also provides the relative importance of these factors for the determination of each country's mix. For heavy borrowers, $K_{i 22}$ is more likely to be higher and the optimal borrowing decision depends on the relative levels of $K_{i 11}$ and $K_{i 21}$. The results of Corollary 3 apply, inducing countries whose weight is large in the EMU, to borrow more on the foreign market than would smaller issuers.

Second, credibility of the no bail out clause has asymmetric impacts. The cost-reducing effect of a decrease in default risk if other countries bail out the one that defaults is included in $K_{i 00}$ and in $K_{i 11}$, but in the latter case this is moderated by a factor $\left(1-\alpha_{i}^{\prime}\right)$. The global resulting increases in the inflation and exchange rates both appear in $K_{i 11}$, which is the only parameter intervening in the determination of the optimal debt proportion, and is essentially a short term factor. Therefore, the lower the credibility of the no bail out clause, the higher the incentive to borrow on the foreign market for countries whose social cost of defaulting on domestic debt is high. Intuitively, if $\alpha_{i}$ is close to 0 , this means that defaulting in the foreign market is not likely to coincide with a default on domestic debt.

Third, parameters that seem unchanged are actually crucial for the assessment of the credit quality of member countries. Specifically, $K_{i 11}$ and $K_{i 22}$ are both very sensitive to credit quality. For $T$ large enough, $K_{i 11}>K_{11}$. In this case, EMU membership could lead to either an increase or a decrease in the optimal debt proportion. However, the impact of the difference between $\alpha_{i}^{\prime}$ and $\alpha_{i}$ is more pronounced for $K_{i 22}$, driving up the optimal ratio. Hence, the greater the difference in social cost of domestic default incurred by entering the EMU, the more pronounced the incentive to issue domestic debt. By contrast, when $T$ is low and if the no bail out clause is not credible (for a high value of $\lambda_{i 0}^{+}$), the effect of monetary union goes univocally towards an increase in the proportion of domestic debt. If the no bail out clause is credible, for low enough maturities, an increase in default risk could lead to a more pronounced foreign indebtedness. 


\section{Optimal coordination policy}

So far, all parameters that were beyond the control of the government have been considered as given, including the $w_{i} D_{i}$, which resulted from the same optimization process from other countries. However, if they were all to try to do this at the same time, they would need to know each other's choice of weights and debt proportions, which can only be done with some coordination. It is sufficient just to optimize the joint problem, of course, but the practical implementation of this exercise would require either strong political integration or considerable market pressure. We introduce a Pareto efficient coordination procedure by a central borrowing agency. For the EMU as a whole, the total cost of debt is the weighted sum of the individual costs. By minimizing this sum, a central agency could fix the optimal domestic debt level, and reallocate this issue to individual countries using the same optimization process at the country level, hereby decreasing the vulnerability of the aggregate sovereign debt.

To illustrate this idea, consider a situation where all countries wish to issue debt with the same maturity $T$, but where they differ with respect to their weight in total debt, their total debt process and their default risk. The coordination of debt policies by a central agency allows us to formulate the following Proposition:

Proposition 7 If each of the $N$ EMU member countries issues at the same time $w_{i}$ face value units of government debt with identical maturity $T$, with $\sum_{i} w_{i}=1$, through a proportion $D_{i}$ of domestic debt and the rest of foreign debt, the debt allocation

$$
\left\{D_{1}, D_{2}, \ldots, D_{N}\right\}=\arg \left\{D_{1}=D_{1}^{o p t} ; D_{2}=D_{2}^{o p t} ; \ldots ; D_{N}=D_{N}^{o p t} ; \sum_{i=1}^{N} w_{i} D_{i}=D_{E}^{o p t}\right\}
$$

where $D_{E}^{o p t}=\arg \min \sum_{i=1}^{N} w_{i} C_{i}(0)$ characterizes a Pareto efficient Nash equilibrium.

Such an allocation could not be made by countries alone, because fixing the aggregate debt level gives them the incentive to borrow fully on either market, depending on the behavior of the default spread. On the other hand, focusing on the determination of the optimal global borrowing is impossible without knowing the allocation of domestic debt among member countries, as the associated default risks appear in the total cost function. These two problems cannot be disentangled, nor can they be solved individually. This result corresponds to the idea put forward by Nielsen (1999) more than a decade before the 2010 Greek crisis. He emphasizes the need for a mechanism that would coordinate debt management policies. Such a coordination accompanies the determination of the optimal aggregate debt. If the determination of all debt is not simultaneous, Proposition 7 collapses to Corollary 6 . 


\section{Structural evolution of EMU debt mix}

We examine whether our theoretical framework is consistent with some of the observed debt structure developments by analyzing the evolution of sovereign debt mix around the creation of EMU. The key drivers of the evolution of sovereign debt issued by EMU members are reviewed before and after the adoption of the single currency in 1999. The effectiveness and the appropriateness of their debt management are analyzed in light our efficiency indicators. We first review the evolution of the key structural and strategic variables. We then introduce the calibrated values of the parameters in our model and verify whether the actual debt mix and maturities are in line with the theoretical predictions driving to a minimization of the cost of debt.

Before the EMU, Austria and Finland exhibited a higher proportion of foreign debt than the other future EMU countries (Table 1). This empirical finding is especially strong for Finland, for which the proportion of foreign debt was even above $50 \%$ in 1994 and $1995 .{ }^{7}$ The observed evolution of the Finnish case can be understood through our theoretical cost-minimization model. Table 2 reports the mean values of the different key variables of the model during the 1994-1998 period.

Insert Table 2 approximately here

Our model predicts that Finnish debt should have a fully foreign structure before the EMU $\left(D^{t h}=0 \%\right)$. The strategic exchange rate risk indicator, $K_{21}$, is positive and exhibits the highest coefficient after Italy. Therefore, the impact of debt management on the exchange rate in the foreign economy is quite strong. The default, devaluation and liquidity risk indicator $K_{11}$ is globally large and positive, which also favors foreign debt. Note that these stylized facts mostly result from the relatively low intrinsic default risk and the very high net intrinsic devaluation and liquidity risks. The signs of $\alpha_{i}$ (positive) and $\beta_{i}$ (negative) indicate further why foreign debt is preferred. The propensity to default on domestic debt (conditional on defaulting on foreign debt) is positive, while the indirect impact of a devaluation of the domestic currency on foreign debt is negative. Finally, the opportunity cost indicator $K_{22}$ is negative. The savings obtained by taking on domestic debt are small and presumably slightly higher than the opportunity cost if foreign debt is used instead, but this fact does not offset the importance of $K_{11}$. In other words, $X+Y>0$. This latter observation could explain why Finland has limited the proportion of foreign debt. These results show that the Finnish debt structure was not inconsistent with an efficient cost minimization policy.

\footnotetext{
${ }^{7}$ Yearly data and estimates are available upon request.
} 
Parameters are also consistent with likely higher foreign debt ratios for Austria. Our estimation suggests that optimality requires a very high amount of proportion debt $\left(K_{11}\right.$ is strongly positive and $K_{22}$ slightly negative). Some elements could have induced Austria to restrain this proportion. The intrinsic devaluation and liquidity risk are much lower than in Finland, since the Austrian schilling was somehow pegged to the German mark, which may justify less relative foreign debt. A negative $\alpha_{i}$ suggests significant social and political costs of defaulting on domestic debt. Similarly, $\beta_{i}$ is positive, translating a greater impact of a devaluation on foreign debt. These examples illustrate that each indicator of the model cannot be considered in isolation. Only the combined effect determines the appropriateness of the debt structure.

Our theoretical model is also consistent with the pattern exhibited by Italy. A higher uncertainty and a strongly negative $K_{11}$ clearly limits the use of foreign debt. Positive values of $\alpha_{i}$ and $\beta_{i}$ both suggest that the market expected a significant impact of a devaluation of the lira on the Italian foreign debt. Our model predicts $100 \%$ domestic debt for Italy while the actual average ratio was $92.8 \%$. One coefficient in favor of lower domestic debt is the opportunity cost indicator, $K_{22}$, that is slightly positive, but overall $X+Y<0$.

The case of the Netherlands, whose proportion of foreign debt is nil (Table 1), is also instructive. The Dutch solution is therefore an extreme one. This empirical finding is hardly unexpected and can be explained by the theoretical model that also predicts $D^{t h}=100 \%$. Another point is also the average term to maturity of the total (domestic) Dutch debt that is relatively higher than in other future EMU countries, and this does not favor mixed borrowing. The other future EMU members exhibit coefficients favoring more domestic debt. For example, we obtain for France and Spain negative $K_{11}$ and $K_{22}$, all of which clearly call for the observed domestic debt proportions of almost $100 \%$.

The introduction of the euro and the EMU has led to dramatic changes for all countries. A general decline in the proportion of foreign debt is observed among all the EMU members. Remarkably, Finland's proportion of foreign debt plummets from $61.2 \%$ in 1994 to $0 \%$ in 2007. Similarly, Irish foreign debt drops from $39.4 \%$ in 1995 to nil in 2003. In contrast, before the EMU, these two countries have good reasons to issue relatively higher proportions of foreign debt. However, after 1999, they are induced to reduce sharply this proportion. According to our framework, heavy borrowers should borrow more on the foreign market. Together with Portugal, Finland and Ireland report the lowest borrowing weights in the total debt in the eurozone. The fact that they are light borrowers is probably not the only reason. At the same time, the other countries are also led to reduce the proportion of foreign debt, but more smoothly than Finland and Ireland. 
Insert Table 3 approximately here

Table 3 reports the model coefficients calibrated on the period following the introduction of the euro. Our model supports clearly a corner solution for all countries. All these countries should have $100 \%$ domestic debt. They all report a strongly negative $K_{11}$, which favors a high proportion of domestic debt. This strong effect is not offset by $K_{21}$ and $K_{22}$, namely $2 X+Y<0$. This common move is understandable with our model. For example, we first consider Austria. Similar to Finland and Ireland, Austria has decreased its foreign debt ratio from $25.7 \%$ in 1994 to $2.3 \%$ in 2010 . For that country, $K_{11}$ is already negative without the variance term (-4.7) according to our estimation. In $K_{i 11}$, the evolution of the credit-related component the first term of this expression is negative. It is interesting to notice that $\alpha_{i} \phi_{i 0}, \alpha_{i} \phi_{i t}^{\prime}$, and $\alpha_{i} \phi_{\gamma}$ have all changed their sign, which may suggest that the sign of $\alpha_{i}$ has changed from negative to positive, which means that defaulting in the foreign market is now more likely to coincide with default on domestic debt.

Finland also has a $K_{11}$ that is strongly negative - even without the variance term. The sign of $\alpha_{i}$ has also changed, but in contrast to Austria, $\alpha_{i}$ becomes negative, suggesting that social and political cost on defaulting on domestic debt has increased, leading to the preference for domestic debt. The variance has fallen, which could be partly explained by the disappearance of devaluation risk. The situation of Italy did not change compared to the ex-ante EMU period. $K_{11}$ is still negative, $\alpha_{i}$ and $K_{22}$ are still positive.

Belgium and Ireland report full domestic debt in 2010. Their patterns are also consistent with those of Austria, Finland and Italy. $K_{11}$ is strongly negative for these countries as well, leading to a full domestic debt solution and $\alpha_{i}$ is positive. For Ireland, the variance is quite significant and $K_{11}$ is positive before subtracting the variance term.

\section{Conclusion}

Since the recent EMU sovereign debt crisis, market participants have been scrutinizing more than ever for (un)sustainable debt levels in assessing default risks. Beyond fiscal policies and total debt to GDP levels, investors should not overlook the government debt currency structure and its corresponding maturity in their valuation. We show that these issues are intimately related, because debt choice is a matter of trade-off between different sources of costs. Through a simple pricing model, this paper derives indicators to assess the efficiency of the debt mix choice by a government. Indicators favoring mixed borrowing are shown to be mostly determined by a set of intrinsic characteristics for those whose cost of domestic debt is large. It 
thus calls for recourse to the foreign market, while strategic factors are more crucial for countries choosing to borrow on the domestic market. Departures from an optimal combination of domestic and foreign debt would increase both the total yield spread of the country and its vulnerability to sovereign debt crises.

The situation before the EMU is characterized by the very dissimilar nature of yields attached to the alternative markets. The change in borrowing conditions can be perceived by the considerable dilution of each country's effect on exchange rate risks into the cost of debt function, and the consequences of the perceived lack of credibility of the no bail out clause are sensitive to short term debt. These consequences are asymmetric: their benefits depend on each country's propensity to default on domestic debt, while their costs are commonly shared. Furthermore, the modifications in credit quality seem to favor higher proportions of domestic debt at the optimum, especially for long term debt. Sovereign debt data seem roughly consistent with our theoretical model, but the analysis of the combined effect of each intrinsic and strategic variable is important to determine whether the chosen debt mix is optimal.

Introducing the euro as a single currency and the conduct of an independent monetary policy at the level of the EMU should have opened up the way to a reflection on the appropriateness of the debt mix at the European level. Our results indicate a steady decline in the proportion of foreign debt after the introduction of the euro, which is consistent with the strong negative structural inflation in the EMU. This could be the result of the primary task of the ECB, which is the fight against inflation. One should now to consider whether an independent monetary policy is consistent with allowing governments to decide freely on their debt currency mix, which comes after the setting of the sovereign government expenditures and tax policies.

The decision of many European countries to primarily issue euro-denominated debt, although broadly consistent with our prediction, leads to corner solutions that might not be fully cost-effective. Given the large overall outstanding debt of EMU countries underpinning the sovereign debt crisis, European governments should not overlook the importance of finding sources of cost savings, and we believe that the currency decision should contribute to this reflection. We emphasize that a central, coordinated approach to determine debt levels and maturities could result in a Pareto efficient equilibrium. The idea of issuing "euro bonds", following the Greece debt crisis, is a step going in that direction, but it is motivated by urgency. Long-term economic gains shared across the EMU countries could be achieved by designing a structural mechanism that manages debt composition for the benefit of all. This could further reassure investors about the efficiency and the credibility of the sovereign debt structure in the EMU. 


\section{References}

Alesina, A.; De Broeck, M.; Prati, A.; Tabellini, G. (1992) Default risk on government debt in OECD countries. Economic Policy 7:427-463.

Alesina, A., Grilli, V. (1995) Reshaping monetary politics in Europe. In: Monetary and Fiscal Policy. Volume 1:

Credibility, Persson, T., and Tabellini G., eds, Cambridge, MA: MIT Press.

Amihud, Y., Mendelson, H. (1991) Liquidity, maturity, and the yields on U.S. Treasury securities. Journal of Finance 46:1411-1425.

Arnold, I., Lemmen, J. (2001) The vulnerability of banks to government default risk in the EMU. International Finance 4:101-125.

Attinasi, M.; Checherita, C.; Nickel, C. (2009) What explains the surge in euro area sovereign spreads during the financial crisis of 2007-09? ECB working paper 1131.

Babbel, D.; Merrill, C.; Meyer, M.; de Villiers, M. (2004) The effect of transaction size on off-the-run treasury price. Journal of Financial and Quantitative Analysis 39:1-28.

Baum, C.; Barkoulas, J.; Caglayan, M. (1999) Persistence in international inflation rates. Southern Economic Journal 65:900-913.

Beber, A; Brandt, M.; Kavajecz, K. (2009) Flight-to-Quality or Flight-to-Liquidity? Evidence From the Euro-Area Bond Market.Review of Financial Studies 22:925-957.

Bernoth, K.; Von Hagen, J.; Schuknecht, L. (2004) Sovereign risk premia in the European government bond market. European Central Bank Working Paper no. 369.

Blanco, R. (2001) The Euro-area government securities markets. Recent developments and implications for market functioning. Banco de España, Servicio de Estudios. Documento de Trabajo no.0120 .

Bohn, H. (1988) Why do we have nominal government debt?. Journal of Monetary Economics 21:127-140.

Bohn, H. (1990) A positive theory of foreign currency debt. Journal of International Economics 29: $273-292$.

Bullow, J., Rogoff, K.(1989) A constant recontracting model of sovereign debt. Journal of Political Economy $97: 155-178$.

Claessens, S.; Klingebiel, D.; Schmukler, S. (2004) Government bonds in domestic and foreign currency: The role of institutional factors. ICFAI Journal of Public Finance 2:7-33.

Codogno, L.; Favero, C.; Missale, A. (2003) Yield spreads on EMU government bonds. Economic Policy 18:503532. 
Crabbe, L., Turner, C. (1995) Does the liquidity of a debt issue increase with size? Evidence from the corporate bond and medium-term note markets. Journal of Finance 50:1719-1734.

Diamond, D., Dybvig, P. (1983) Bank runs, deposit insurance and liquidity. Journal of Political Economy 91:401419.

Duffie, D., Singleton, K. (1999) Modeling term structures of defaultable bonds. Review of Financial Studies 12:687-720.

Ejsing, J.; Lemke, W. (2011) The Janus-headed salvation: sovereign and bank credit risk premia during 2008-2009. Economic Letters 110:28-31.

Faini, R. (2006) Fiscal policy and interest rates in Europe. Economic Policy 21:443-489.

Favero, C.; Giavazzi, F.; Spaventa, L.(1997) High yields: the spread on German interest rates. The Economic Journal 107:956-985.

Favero, C.; Pagano, M.; Von Thadden E.-L. (2010) How does liquidity affect government bond yields?. Journal of Financial and Quantitative Analysis 45:107-134.

Fleming, M.(2002) Are larger Treasury issues more liquid? Evidence from bill reopenings. Journal of Money, Credit, and Banking 34:707-735.

Geyer, A.; Kossmeier, S.; Pichler, S. (2004) Measuring systematic risk in EMU government yield spreads. Review of Finance 8:171-197.

Giavazzi, F., Pagano, M. (1990) Confidence crises and public debt management. In: Public Debt Management: Theory and History, Dornbusch, R., and Draghi, M., eds, Cambridge, MA: Cambridge University Press.

Gilson, N., Gérard, M. (2002) Currency composition and public debt in EMU. Info-Studien 48:301-322.

Gomez-Puig, M.(2009) Systemic and idiosyncratic risk in EU-15 sovereign yield spreads after seven years of monetary union. European Financial Management 15: 971-1000.

Gomez-Puig, M.(2008) Monetary integration and the cost of borrowing. Journal of International Money and Finance 27:455-479.

Gomez-Puig, M.(2006) Size matters for liquidity: evidence from EMU sovereign yield spreads. Economics Letters 90:156-162.

Hassler, U., Wolters, J. (1995) Long memory in inflation rates: international evidence. Journal of Business and Economic Statistics 13:37-45.

Haugh, D.; Ollivaud, P.; Turner, D. (2009) What drives sovereign risk premiums? An analysis of recent evidence 
from the Euro area. OECD Economics Department Working paper 718.

Jankowitsch, R.; Mösenbacher, H.; Pichler, S.(2006) Measuring the liquidity impact on EMU government bond prices. European Journal of Finance 12:153-169.

Kamara, A.(1994) Liquidity, taxes, and short-term treasury yields. Journal of Financial and Quantitative Analysis 29:403-417.

Kremer, M., Mehta, P. (2000) Globalization and international public finance. NBER Working Paper $\mathrm{n}^{\circ} 7575$.

Krishnamurthy, A. (2002) The bond/old-bond spread. Journal of Financial Economics 66:463-506.

Manganelli, S., Wolswijk, G. (2009) What drives spreads in the euro area government bond market?. Economic Policy 24:191-240.

Miller, V. (1997) Why a government might want to consider foreign currency denominated debt. Economics Letters 55:247-250.

Missale, A., Blanchard, O. (1994) The debt burden and debt maturity. American Economic Review 84:309-319.

Nielsen, L. (1999) Yield spreads and optimal public debt management under the single currency. In: European Capital Markets with a Single Currency, Dermine, J., and Hillion, P., eds, Oxford University Press.

Organisation for Economic Co-operation and Development (OECD).(2011) Central Government Debt. Statistical Yearbook 2001-2010. OECD Publishing.

Organisation for Economic Co-operation and Development (OECD).(2005) Central Government Debt. Statistical Yearbook 1994-2003. OECD Publishing.

Pagano, M., Von Thadden, E.-L. (2004) The European bond markets under EMU. Oxford Review of Economic Policy 20:531-554.

Strebulaev, I. (2002) Liquidity and asset pricing: evidence from the U.S. Treasury securities. London Business School working paper.

Summers, L. (1984) The Nonadjustment of Nominal Interest Rates: A Study of the Fisher Effect" NBER Working Paper No. 836 .

Warga, A. (1992) Bond returns, liquidity, and missing data. Journal of Financial and Quantitative Analysis 27:605-617.

Wolswijk, G., de Haan, J. (2006) Government debt management in Europe: recent changes in debt managers' strategies. Public Finance and Management 6:244-277. 
Table 1. Average yield spreads and debt ratios.

\begin{tabular}{|c|c|c|c|c|c|c|c|c|c|c|c|c|c|}
\hline & \multicolumn{7}{|c|}{ Spread data (in bps) } & \multicolumn{6}{|c|}{ Debt ratios (in \%) } \\
\hline & \multirow{2}{*}{$\frac{\text { Swap }}{\text { pre }}$} & \multicolumn{2}{|c|}{ Default } & \multicolumn{2}{|c|}{ Liquidity } & \multicolumn{2}{|c|}{ Total } & \multicolumn{2}{|c|}{ Tot./GDP } & \multicolumn{2}{|c|}{ Mkt./GDP } & \multicolumn{2}{|c|}{ Foreign } \\
\hline & & pre & post & pre & post & pre & post & pre & post & pre & post & pre & post \\
\hline GER & - & - & - & -1.0 & 2.7 & & & 23.0 & 39.5 & 19.8 & 36.4 & 0.0 & 0.2 \\
\hline AUS & 1.9 & 9.3 & 17.2 & 3.5 & 2.6 & 14.8 & 19.7 & 57.2 & 61.5 & 43.6 & 54.3 & 26.4 & 8.9 \\
\hline BEL & 25.5 & 11.1 & 21.2 & 7.6 & 4.5 & 42.7 & 25.6 & 111 & 94.6 & 102 & 87.5 & 6.6 & 0.9 \\
\hline FIN & 66.8 & -9.8 & 4.0 & 18.6 & 9.6 & 70.9 & 12.7 & 62.6 & 40.7 & 54.1 & 38.0 & 47.0 & 5.7 \\
\hline FRA & 13.4 & 6.0 & 12.5 & 3.6 & 0.8 & 23.0 & 13.3 & 43.2 & 53.1 & 38.1 & 49.7 & 5.9 & 0.0 \\
\hline IRL & 53.7 & 4.7 & 37.7 & 10.4 & 10.3 & 58.2 & 46.3 & 64.2 & 32.4 & 56.4 & 31.0 & 33.3 & 1.7 \\
\hline ITA & 231 & 39.8 & 38.2 & 10.1 & 3.3 & 277 & 41.6 & 112 & 101 & 103 & 89.6 & 7.2 & 1.8 \\
\hline NET & 0.7 & -7.2 & 9.0 & 6.5 & 3.9 & 0.1 & 12.9 & 56.0 & 44.5 & 47.4 & 43.4 & 0.0 & 0.6 \\
\hline POR & 228 & 13.4 & 41.3 & $\mathrm{~N} / \mathrm{A}$ & 5.6 & 241 & 46.9 & 57.4 & 64.3 & 41.1 & 51.1 & $\mathrm{~N} / \mathrm{A}$ & 2.4 \\
\hline SPA & 204 & 13.6 & 25.4 & 6.1 & 5.1 & 224 & 30.1 & 53.5 & 41.9 & 47.6 & 40.0 & 2.7 & 2.3 \\
\hline
\end{tabular}

This table reports on the left panel the average swap spread, the default spread, the liquidity spread and the total yield spread for the benchmark 10-year government bonds. On the right panel, the table reports the ratios of average total government debt-to-GDP, average marketable debt-to-GDP, and debt denominated in foreign currency to marketable debt for 10 member countries of the EMU. Spread data are computed as differences with respect to the German benchmark 10-year government bond and swap rates. The pre-EMU period columns report the average values between 1994 and 1998. The post-EMU period columns report the average values between 1999 and 2010. The swap spread represents the yield spread on 10-year swap contracts. The default yield spread is the difference between the total yield spread and the swap spread minus the liquidity spread. The liquidity spread is computed from the difference between the yields of on-the-run and off-the-run 10-year government bonds. Country codes: GER=Germany, AUS=Austria, BEL=Belgium, FIN=Finland, FRA=France, IRL=Ireland, ITA=Italy, NET=the Netherlands, $\mathrm{POR}=$ Portugal and $\mathrm{SPA}=$ Spain. Data come from Thomson Financial Datastream and from Central Government Debt Statistical Yearbooks 1994-2010 (OECD Publishing). 
Table 2. Calibrated model coefficients \& predictions- pre-EMU period.

\begin{tabular}{|c|c|c|c|c|c|c|c|c|c|}
\hline & \multicolumn{9}{|c|}{ Panel A: Model Coefficients } \\
\hline & AUS & BEL & FIN & FRA & IRL & ITA & NET & POR & SPA \\
\hline$\gamma_{0}$ & 52.3 & 118.6 & 61.7 & 37.02 & 85.08 & 115.6 & 60.8 & $\mathrm{~N} / \mathrm{A}$ & 50.6 \\
\hline$\gamma_{D}$ & 0.02 & -0.02 & 0.005 & 0.02 & -0.10 & -0.01 & -0.02 & $\mathrm{~N} / \mathrm{A}$ & 0.01 \\
\hline$\gamma_{F}$ & 0.05 & -0.42 & 0.03 & 0.21 & -0.36 & -0.17 & 0 & $\mathrm{~N} / \mathrm{A}$ & 0.23 \\
\hline$x_{t}$ & -0.01 & -0.02 & -0.12 & -0.005 & -0.05 & -0.0002 & -0.01 & $\mathrm{~N} / \mathrm{A}$ & -0.01 \\
\hline$x_{D}$ & -0.004 & 0.01 & 0.02 & -0.0004 & 0.01 & 0.04 & 0 & $\mathrm{~N} / \mathrm{A}$ & 0.01 \\
\hline$\phi_{\gamma}$ & 1.5 & $\mathrm{~N} / \mathrm{A}$ & -9.1 & $\mathrm{~N} / \mathrm{A}$ & $\mathrm{N} / \mathrm{A}$ & 6.1 & $\mathrm{~N} / \mathrm{A}$ & $\mathrm{N} / \mathrm{A}$ & $\mathrm{N} / \mathrm{A}$ \\
\hline$\alpha \phi_{\gamma}$ & -6.2 & $\mathrm{~N} / \mathrm{A}$ & -9.6 & 0.8 & $\mathrm{~N} / \mathrm{A}$ & 5.12 & -1.3 & $\mathrm{~N} / \mathrm{A}$ & 1.9 \\
\hline$\delta_{\gamma}$ & -3.9 & $\mathrm{~N} / \mathrm{A}$ & -3.8 & -8.4 & $\mathrm{~N} / \mathrm{A}$ & 76.9 & -0.2 & $\mathrm{~N} / \mathrm{A}$ & 22.1 \\
\hline$\beta \delta_{\gamma}$ & -1.4 & $\mathrm{~N} / \mathrm{A}$ & 2.1 & $\mathrm{~N} / \mathrm{A}$ & $\mathrm{N} / \mathrm{A}$ & 62.1 & $\mathrm{~N} / \mathrm{A}$ & $\mathrm{N} / \mathrm{A}$ & $\mathrm{N} / \mathrm{A}$ \\
\hline$\psi_{\gamma}$ & -0.8 & $\mathrm{~N} / \mathrm{A}$ & -5.1 & -1.4 & $\mathrm{~N} / \mathrm{A}$ & -3.2 & -0.002 & $\mathrm{~N} / \mathrm{A}$ & -1.8 \\
\hline$\mu \psi_{\gamma}$ & -1.4 & $\mathrm{~N} / \mathrm{A}$ & -1.8 & $\mathrm{~N} / \mathrm{A}$ & $\mathrm{N} / \mathrm{A}$ & -6.0 & $\mathrm{~N} / \mathrm{A}$ & $\mathrm{N} / \mathrm{A}$ & $\mathrm{N} / \mathrm{A}$ \\
\hline$\phi_{0}$ & -218.8 & $\mathrm{~N} / \mathrm{A}$ & 526.8 & $\mathrm{~N} / \mathrm{A}$ & $\mathrm{N} / \mathrm{A}$ & -751.6 & $\mathrm{~N} / \mathrm{A}$ & $\mathrm{N} / \mathrm{A}$ & $\mathrm{N} / \mathrm{A}$ \\
\hline$\alpha \phi_{0}$ & 619.0 & $\mathrm{~N} / \mathrm{A}$ & 630.4 & -128.1 & $\mathrm{~N} / \mathrm{A}$ & -392.2 & 48.6 & $\mathrm{~N} / \mathrm{A}$ & -76.6 \\
\hline$\alpha \phi_{t}$ & -0.6 & $\mathrm{~N} / \mathrm{A}$ & -0.11 & 0.22 & $\mathrm{~N} / \mathrm{A}$ & -0.33 & 0.03 & $\mathrm{~N} / \mathrm{A}$ & -0.04 \\
\hline$\delta_{0}$ & 311.3 & $\mathrm{~N} / \mathrm{A}$ & 598.6 & 705.9 & $\mathrm{~N} / \mathrm{A}$ & -8975 & -80.2 & $\mathrm{~N} / \mathrm{A}$ & 2066.1 \\
\hline$\beta \delta_{0}$ & 38.9 & $\mathrm{~N} / \mathrm{A}$ & -523.8 & $\mathrm{~N} / \mathrm{A}$ & $\mathrm{N} / \mathrm{A}$ & -6583 & $\mathrm{~N} / \mathrm{A}$ & $\mathrm{N} / \mathrm{A}$ & $\mathrm{N} / \mathrm{A}$ \\
\hline$\beta \delta_{t}$ & 0.22 & $\mathrm{~N} / \mathrm{A}$ & 2.05 & $\mathrm{~N} / \mathrm{A}$ & $\mathrm{N} / \mathrm{A}$ & -2.4 & $\mathrm{~N} / \mathrm{A}$ & $\mathrm{N} / \mathrm{A}$ & $\mathrm{N} / \mathrm{A}$ \\
\hline$\psi_{0}$ & 36.4 & $\mathrm{~N} / \mathrm{A}$ & 522.6 & 197.1 & $\mathrm{~N} / \mathrm{A}$ & 327.7 & -7.5 & $\mathrm{~N} / \mathrm{A}$ & 79.5 \\
\hline$\mu \psi_{0}$ & 86.6 & $\mathrm{~N} / \mathrm{A}$ & -105.6 & $\mathrm{~N} / \mathrm{A}$ & $\mathrm{N} / \mathrm{A}$ & 646.7 & $\mathrm{~N} / \mathrm{A}$ & $\mathrm{N} / \mathrm{A}$ & $\mathrm{N} / \mathrm{A}$ \\
\hline$\mu \psi_{t}$ & 0.0 & $\mathrm{~N} / \mathrm{A}$ & 1.12 & $\mathrm{~N} / \mathrm{A}$ & $\mathrm{N} / \mathrm{A}$ & 0.7 & $\mathrm{~N} / \mathrm{A}$ & $\mathrm{N} / \mathrm{A}$ & $\mathrm{N} / \mathrm{A}$ \\
\hline
\end{tabular}




\begin{tabular}{|c|c|c|c|c|c|c|c|c|c|}
\hline \multirow[b]{2}{*}{$K_{11}$} & \multicolumn{9}{|c|}{ Panel B: Model prediction vs. actual movement } \\
\hline & + & - & + & - & - & - & - & $\mathrm{N} / \mathrm{A}$ & - \\
\hline$K_{21}$ & - & + & + & - & + & + & 0 & $\mathrm{~N} / \mathrm{A}$ & + \\
\hline$K_{22}$ & - & $\mathrm{N} / \mathrm{A}$ & - & - & $\mathrm{N} / \mathrm{A}$ & + & + & $\mathrm{N} / \mathrm{A}$ & - \\
\hline$X+Y$ & + & + & + & - & + & - & - & $\mathrm{N} / \mathrm{A}$ & - \\
\hline$\Delta t_{d, f}$ & 2.3 & $\mathrm{~N} / \mathrm{A}$ & 1.4 & $\mathrm{~N} / \mathrm{A}$ & -3 & 2.9 & -6.5 & $\mathrm{~N} / \mathrm{A}$ & $\mathrm{N} / \mathrm{A}$ \\
\hline$D^{t h}(\%)$ & $\mathrm{D}=0$ & $0<\mathrm{D}<100$ & $\mathrm{D}=0$ & $\mathrm{D}=100$ & $0<\mathrm{D}<100$ & $\mathrm{D}=100$ & $\mathrm{D}=100$ & $\mathrm{~N} / \mathrm{A}$ & $\mathrm{D}=100$ \\
\hline$\overline{\mathbf{D}}^{a c t}(\%)$ & 73.5 & 93.4 & 53.0 & 94.1 & 66.7 & 92.8 & 100 & $\mathrm{~N} / \mathrm{A}$ & 97.3 \\
\hline
\end{tabular}

Panel A of this table reports the calibrated coefficients of the debt ratio, swap spread, liquidity spread and default spread process during the $1994-1998$ period. $\gamma_{D}$ (resp. $\left.\gamma_{F}\right)$ is the rate of change between the total debt to GDP ratio $\Gamma_{t}$ and the proportion of domestic debt $D$ (resp. foreign debt $F$ ), proxied by the slope of the linear regression between the two variables, $\gamma_{0}$ being the intercept of this regression. $x_{t}$ and $x_{D}$ are jointly estimated from the multiple regression $\ln X_{t}=x_{0}+x_{t} t+x_{D} D+\varphi_{t}$ where $X_{t}$ is the domestic currency nominal effective exchange rate (denominator is the domestic currency) against a group of 40 trading partners. $\alpha \phi_{0}, \alpha \phi_{t}$ and $\alpha \phi_{\gamma}$ are jointly estimated from the multiple regression $\Phi_{t}=\alpha \phi_{0}+\alpha \phi_{t} D t_{d}+\alpha \phi_{\gamma} \Gamma_{t}+\varrho_{t}$ where $\Phi_{t}$ is the default spread proxied by the spread of 10-year benchmark government yield over the corresponding swap spread of the same maturity denominated in the same currency, minus the liquidity spread. $t_{d}$ is the average term to maturity of domestic debt. $\beta \delta_{0}, \beta \delta_{t}$ and $\beta \delta_{\gamma}$ are jointly estimated from the multiple regression. $\Delta_{F t}=\beta \delta_{0}+\beta \delta_{t} F t_{f}+\beta \delta_{\gamma} \Gamma_{t}+\varkappa_{t}$ where $\Delta_{F t}$ is the devaluation spread proxied by the spread of the 10 -year swap rate. $t_{f}$ is the average term to maturity of foreign debt. $\psi_{0}$ is the initial value of $, \mu \psi_{0}, \mu \psi_{t}$ and $\mu \psi_{\gamma}$ are jointly estimated from the multiple regression $\Psi_{F t}=\mu \psi_{0}+\mu \psi_{t} F t_{f}+\mu \psi_{\gamma} \Gamma_{t}+\iota_{t}$ where $\Psi_{F t}$ is the liquidity spread proxied by the spread between the on-therun and off-the-run 10-year benchmark bond yields. $t_{f}$ is the average term to maturity of foreign debt. Panel B reports the likely sign of the three parameters of the model, the likely model prediction for the proportion of domestic currency debt $\left(D^{t h}\right)$ and the actual average proportion $\left(\overline{\mathbf{D}}^{a c t}\right) . \Delta t_{d, f}$ is the average maturity differential between foreign and domestic debt. N/A indicates that the data were not available to estimate the parameter . Country codes: $\mathrm{AUS}=$ Austria, $\mathrm{BEL}=$ Belgium, $\mathrm{FIN}=$ Finland, FRA=France, IRL=Ireland, ITA=Italy, NET=the Netherlands, $\mathrm{POR}=$ Portugal and $\mathrm{SPA}=$ Spain 
Table 3. Calibrated model coefficients - post-EMU period.

\begin{tabular}{|c|c|c|c|c|c|c|c|c|c|}
\hline & \multicolumn{9}{|c|}{ Panel A: Model Coefficients } \\
\hline & AUS & BEL & FIN & FRA & IRL & ITA & NET & POR & SPA \\
\hline$\theta \gamma_{0}$ & 60.3 & 100.5 & 49.8 & 44.3 & 27.8 & 100.6 & 42.2 & 46.2 & 46.9 \\
\hline$\theta \gamma_{D}$ & 0.002 & -0.01 & -0.01 & 0.01 & 0.007 & 0.0003 & 0.004 & 0.03 & -0.007 \\
\hline$\theta \gamma_{F}$ & -0.06 & 0.05 & 0.16 & 0 & 0.17 & -0.43 & 0.29 & 0.27 & -0.72 \\
\hline$\phi_{0}^{\prime}$ & -330.1 & -240.5 & 40.2 & $\mathrm{~N} / \mathrm{A}$ & 50.1 & -556.4 & $\mathrm{~N} / \mathrm{A}$ & $\mathrm{N} / \mathrm{A}$ & $\mathrm{N} / \mathrm{A}$ \\
\hline$\alpha^{\prime} \phi_{0}^{\prime}$ & -364.0 & 6.3 & -66.7 & -58.1 & 55.9 & -721.9 & -133.1 & $\mathrm{~N} / \mathrm{A}$ & -772.2 \\
\hline$\alpha^{\prime} \phi_{t}^{\prime}$ & 0.03 & -0.11 & 0.1 & -0.02 & -0.1 & 0.3 & 0.1 & $\mathrm{~N} / \mathrm{A}$ & 0.8 \\
\hline$\psi_{0}^{\prime}$ & 58.9 & -52.1 & -25.2 & 8.45 & -57.4 & 8.29 & 22.5 & $\mathrm{~N} / \mathrm{A}$ & 95.2 \\
\hline$\mu^{\prime} \psi_{0}^{\prime}$ & 43.5 & -103.1 & -24.3 & $\mathrm{~N} / \mathrm{A}$ & -18.4 & 17.9 & $\mathrm{~N} / \mathrm{A}$ & $\mathrm{N} / \mathrm{A}$ & $\mathrm{N} / \mathrm{A}$ \\
\hline$\mu^{\prime} \psi_{t}^{\prime}$ & 0.06 & -2.3 & -0.2 & $\mathrm{~N} / \mathrm{A}$ & -0.6 & -0.2 & $\mathrm{~N} / \mathrm{A}$ & $\mathrm{N} / \mathrm{A}$ & $\mathrm{N} / \mathrm{A}$ \\
\hline$\phi_{\gamma}^{\prime}$ & 5.7 & 2.84 & -1.2 & $\mathrm{~N} / \mathrm{A}$ & -1.8 & 6.2 & $\mathrm{~N} / \mathrm{A}$ & $\mathrm{N} / \mathrm{A}$ & $\mathrm{N} / \mathrm{A}$ \\
\hline$\alpha^{\prime} \phi_{\gamma}^{\prime}$ & 5.8 & 0.8 & 0.4 & 1.5 & -0.32 & 5.6 & 1.6 & $\mathrm{~N} / \mathrm{A}$ & 6.9 \\
\hline$\psi_{\gamma}^{\prime}$ & -0.8 & 0.3 & 0.2 & -0.03 & 0.6 & -0.1 & 0.2 & $\mathrm{~N} / \mathrm{A}$ & -0.8 \\
\hline$\mu^{\prime} \psi_{\gamma}^{\prime}$ & -0.7 & 1.2 & 1.0 & $\mathrm{~N} / \mathrm{A}$ & 1.0 & -0.1 & $\mathrm{~N} / \mathrm{A}$ & $\mathrm{N} / \mathrm{A}$ & $\mathrm{N} / \mathrm{A}$ \\
\hline$x_{t}$ & -0.001 & -0.001 & -0.001 & -0.001 & -0.001 & -0.001 & -0.001 & -0.001 & -0.001 \\
\hline$x_{D}^{\prime}$ & 0.12 & 0.12 & 0.12 & 0.12 & 0.12 & 0.12 & 0.12 & 0.12 & 0.12 \\
\hline \multirow[t]{2}{*}{$w_{i}$} & 3.2 & 6.1 & 1.4 & 19.5 & 1.0 & 30.6 & 4.9 & 2.1 & 7.7 \\
\hline & \multicolumn{9}{|c|}{ Panel B: Model prediction vs. actual movement } \\
\hline$K_{11}$ & - & - & - & - & - & - & - & $\mathrm{N} / \mathrm{A}$ & - \\
\hline$K_{21}$ & + & + & + & + & + & + & + & + & + \\
\hline$K_{22}$ & + & + & + & - & - & + & + & $\mathrm{N} / \mathrm{A}$ & + \\
\hline $2 X+Y$ & - & - & - & - & - & - & - & $\mathrm{N} / \mathrm{A}$ & - \\
\hline$\Delta t_{d, f}$ & -3.6 & -4.72 & -2.2 & $\mathrm{~N} / \mathrm{A}$ & -3.6 & 2.0 & 0.2 & $\mathrm{~N} / \mathrm{A}$ & $\mathrm{N} / \mathrm{A}$ \\
\hline$D^{t h}$ & $\mathrm{D}=100$ & $\mathrm{D}=100$ & $\mathrm{D}=100$ & $\mathrm{D}=100$ & $\mathrm{D}=100$ & $\mathrm{D}=100$ & $\mathrm{D}=100$ & $\mathrm{~N} / \mathrm{A}$ & $\mathrm{D}=100$ \\
\hline$\overline{\mathbf{D}}^{a c t}$ & 91.1 & 99.1 & 94.3 & 100 & 98.2 & 98.1 & 99.4 & 97.6 & 97.6 \\
\hline
\end{tabular}

Panel A of this table reports the calibrated coefficients of the total debt-to-GDP ratio, exchange rate, liquidity 
spread and default spread process during the 1999-2010 period. $\theta \gamma_{D}\left(\right.$ resp. $\left.\theta \gamma_{F}\right)$ is the rate of change between the total debt to GDP ratio $\Gamma_{t}$ and the proportion of domestic debt $D$ (resp. foreign debt $F$ ), proxied by the slope of the linear regression between the two variables, $\theta \gamma_{0}$ being the intercept of this regression. $\alpha^{\prime} \phi_{0}^{\prime}, \alpha^{\prime} \phi_{t}^{\prime}$ and $\alpha^{\prime} \phi_{\gamma}^{\prime}$ are jointly estimated from the multiple regression $\Phi_{t}^{\prime}=\alpha^{\prime} \phi_{0}^{\prime}+\alpha^{\prime} \phi_{t}^{\prime} D t_{d}+\alpha^{\prime} \phi_{\gamma}^{\prime} \Gamma_{t}+\varrho_{t}^{\prime}$ where $\Phi_{t}^{\prime}$ is the default spread proxied by the spread of 10-year benchmark government yield over the swap spread of the same maturity denominated in euros, minus the liquidity spread. $t_{d}$ is the average term to maturity of domestic debt. $\mu^{\prime} \psi_{0}^{\prime}, \mu^{\prime} \psi_{t}^{\prime}$ and $\mu^{\prime} \psi_{\gamma}^{\prime}$ are jointly estimated from the multiple regression $\Psi_{F t}^{\prime}=\mu^{\prime} \psi_{0}^{\prime}+\mu^{\prime} \psi_{t}^{\prime} F t_{f}+\mu^{\prime} \psi_{\gamma}^{\prime} \Gamma_{t}+\iota_{t}^{\prime}$ where $\Psi_{F t}^{\prime}$ is the liquidity spread proxied by the spread between the on-the-run and off-the-run 10-year benchmark bond yields. $t_{f}$ is the average term to maturity of foreign debt. $w_{i}$ is the weight of the country $i$ 's total debt in the total debt issue in the EMU. $x_{t}$ and $x_{D}$ are jointly estimated from the multiple regression $\ln X_{t}=x_{0}+x_{t} t+x_{D} D+\varphi_{t}$ where $X_{t}$ is the euro nominal effective exchange rate (denominator is the euro) against EER-40 group of trading partners. Panel B reports the likely sign of the three parameters of the model, the likely model prediction for the proportion of domestic currency $\operatorname{debt}\left(D^{t h}\right)$ and the actual average proportion $\left(\overline{\mathbf{D}}^{a c t}\right) . \Delta t_{d, f}$ is the average maturity differential between foreign and domestic debt. AUS=Austria, BEL=Belgium, FIN=Finland, FRA=France, IRL=Ireland, ITA=Italy, NET=the Netherlands, POR=Portugal, SPA=Spain. 